\title{
Efficay of Plant Extracts and Vermiwash on Dynamics of Thrips Population and Yield of Chillies
}

\author{
S. Sendur Kumaran \\ Associate Professor and Head, Krishi Vigyan Kendra, Kundrakudi-630 206, Tamil Nadu, India
}

\begin{abstract}
Any program designed to change pesticide use patterns in chilli cultivation help reduce pesticide usage, incorporation of biorational materials and a knowledge of which materials can be safely integrated is critical and need of the hour for a number of reasons. With this Knowledge, Field trials were carried out during Rabi/summer 2014-15 at Krishi Vigyan Kendra, Kundrakudi to study the effect of Prosopis juliflora and Notchi leaf extracts in combination with vermiwash in different dilutions are studied to protect the crop damage against thrips (Scirtothrips dorsalis) and its contribution to the yield in chilli cv. Priyanka under micro irrigation situations. The results revealed that combined application of Prosopis juliflora leaf extracts@20 ml and Notchi leaf extract @ 20 ml and vermiwash at 1:2 ratio water recorded significantly lesser population of thrips with $228.20 q / h e c$. of dry chilli per hectare followed by Notchi (vitex negundo) leaf extracts @ $20 \mathrm{ml}$ in combination with vermiwash at 1:2 ratio water and registered significantly higher yield were at par with plants grown that received chemical pesticide.
\end{abstract}

Keywords: Scirtothrips dorsalis, Prosopis juliflora, Notchi leaf extracts , vermiwash ,chillies

\section{Introduction}

Chillies, are an important dietary component of Indians .Chilli was first cultivated by the people of Central and South America in around 3000BC. Columbus brought seeds back to Europe in 1493, and from there it has spread to the cuisines of the entire world . India is largest and biggest exporter of chillies in the world with a production of more than 12.74 lakh tonnes of dry chilli from an area of over 9.63 lakh hectares. Among the constraints in chilli cultivation, the attack of a multitude of insect pests particularly thrips at different crop stages is of utmost concern.

Chili thrips (Scirtothrips dorsalis) is a polyphagous pest attacks all the above ground parts of its host plants. .Thrips feed by roughly rubbing (rasping) emerging and new plant parts. The rasping breaks plant tissue that oozes sap on which the insect feeds. Feeding may cause leaves to curl upward and become distorted appearing much like herbicide damage and causes leaf curl symptoms. The Eggs (45-50) are laid inside leaf tissues and tender shoots. Nymphs emerge after about 5 days. Nymphal stage takes 7-8 days and pupal stage, 2-4 days. Life span of adults is about 30 days. Adult insect is $1 \mathrm{~mm}$ long, slender, yellowish-brown with apically pointed wings on males, and narrow with long hairs fringing the fore margins, on females. Nymphs resemble adults but are wingless. Affected leaves and buds become brittle and drop, plants get stunted and bronzed. Chilli thrips feeds on leaf, bud, and fruit tissue to turn bronze in color. Newer leaves are often shiny and older ones are frequently scarred from rasping. Infested plants become stunted and severe infestations can result in total defoliation of the host.

There is a critical need for developing resistance management programs for chilli thrips in particular. There is also a critical need for integrating nonconventional methods with existing cultural and chemical controls. Several forces create this need, but it appears that the major one is to preserve the current organics that are safe, effective and registered. Experimenting trails to change pesticide use patterns in chilli cultivation help reduce pesticide usage and incorporation of organic volatiles are needed. With this Knowledge, the effects of Prosopis juliflora and Notchi leaf extracts in combination with vermiwash in different dilutions are studied to protect the crop damage from thrips and its contribution to the yield.

\section{Materials and Methods}

Prosopis juliflora and notchi leaf extracts (10ml in 1 litre of water each); and Vermiwash at three dilutions viz.,1:2,1:4,1:6 were prepared by mixing with water were used for the treatment. Five rounds of foliar spray were given to evaluate its efficacy against thrips. Vermiwash was obtained by culturing Eudrilus earthworms on organic substrates. Recommended dose of fertilizer along with chemical (dimethoate) sprays was maintained as standard check. Field investigations were conducted for the evaluation of Prosopis juliflora and vermiwash in the management of thrips, Scirtothrips dorsalis on chilli (cV. Priyanka) during Rabi/summer 2012-13 at Krishi Vigyan Kendra, Kundrakudi under rain fed situations.

Protray seedlings of chilli required for the experiment was transplanted during the second fortnight of November in raised bed plots with size 20 foot (length) $\mathrm{x} 4$ foot(wide) $\mathrm{x}$ 0.5 foot (height) with spacing of $2 \times 2$ foot. All the management practices except plant protection measures against Scirtothrips dorsalis and plant nutrition were followed as per the recommended dose (RD) of practices (Spears, 2006). The field experiments were laid out in a randomized block design with 7 treatments involving the Prosopis juliflora and Notchi leaf extracts, Vermiwash in different dilutions along with recommended doses of organic and inorganic fertilizers, which was replicated thrice. In each replication five plants were selected randomly and utilized 


\section{International Journal of Science and Research (IJSR) \\ ISSN (Online): 2319-7064 \\ Index Copernicus Value (2013): 6.14 | Impact Factor (2015): 6.391}

for recording observations on the population of thrips as per the destructive sampling methods as suggested by Reddy and Puttaswamy (1984).

\section{Treatment details}

\begin{tabular}{|c|l|}
\hline Treatment & \multicolumn{1}{|c|}{ Nature of Treatment } \\
\hline $\mathrm{T}_{1}$ & $\begin{array}{l}\text { Prosopis juliflora leaf extracts (20ml/lit. of } \\
\text { water)alone + RD }\end{array}$ \\
\hline $\mathrm{T}_{2}$ & Notchi leaf extract(20ml/lit. of water) + RD \\
\hline $\mathrm{T}_{3}$ & $\begin{array}{l}\text { Prosopis juliflora leaf extract (20ml/lit. of water) }+ \\
\text { Notchi leaf extract(20ml/lit. of water) + RD }\end{array}$ \\
\hline $\mathrm{T}_{4}$ & $\begin{array}{l}\text { Prosopis juliflora leaf extract (20ml/lit. of water) }+ \\
\text { Notchi leaf extract(20ml/lit. of water) + Vermiwash } \\
1: 2+\text { RD }\end{array}$ \\
\hline $\mathrm{T}_{5}$ & $\begin{array}{l}\text { Prosopis juliflora leaf extract (20ml/lit. of water) }+ \\
\text { Notchi leaf extract(20ml/lit. of water) + Vermiwash } \\
1: 4+\text { RD }\end{array}$ \\
\hline $\mathrm{T}_{6}$ & $\begin{array}{l}\text { Prosopis juliflora leaf extract (20ml/lit. of water) }+ \\
\text { Notchi leaf extract(20ml/lit. of water) + Vermiwash } \\
1: 6+\text { RD }\end{array}$ \\
\hline $\mathrm{T}_{7}$ & RD+ Imidacloprid chemical spray \\
\hline
\end{tabular}

Recommended dose (RD)-FYM24t+NPK 150:100:50 kg

+Azospirillium $2 \mathrm{~kg}$ +Phosphobacteria 2 kg ha-1)

\section{Results and Discussion}

The effect of Prosopis juliflora and Notchi leaf extracts; and Vermiwash interventions on dynamics of thrips, S. dorsalis populations are presented in table1 and 2 .

The mean population of thrips /leaf, Plant height(m), Number of branches per plant, Number of fruits/plant and yield of dry chilli (q/ha) are important contributors towards the economic yield. This is made possible by the advancement in managerial practices like proper spray of Prosopis juliflora, Notchi leaf extracts; and Vermiwash sprays and use of recommended dose of fertilizers Giraddi et al. (2003). Moreover, chilli, being a dietary vegetable, responds well to the fertilizers (Buckerfield et. al., 1999) and organic repellent spray(Spears , 2006)

Table 1: Mean population of thrips and yield; and its contributing traits as influenced by Prosopis juliflora, Notchi leaf extracts; and Vermiwash sprays

\begin{tabular}{|c|c|c|c|c|}
\hline S. No. & Treatments & $\begin{array}{c}\text { mean thrips } \\
\text { population/leaf }\end{array}$ & $\begin{array}{c}\text { Plant } \\
\text { height }(\mathrm{m})\end{array}$ & $\begin{array}{c}\text { No. of branches } \\
\text { per plant }\end{array}$ \\
\hline 1 & $\mathrm{~T}_{1}$ & 0.53 & 0.60 & 16.54 \\
\hline 2 & $\mathrm{~T}_{2}$ & 0.49 & 0.61 & 17.65 \\
\hline 3 & $\mathrm{~T}_{3}$ & 0.44 & 0.64 & 17.12 \\
\hline 4 & $\mathrm{~T}_{4}$ & 0.23 & 0.84 & 24.30 \\
\hline 5 & $\mathrm{~T}_{5}$ & 0.34 & 0.75 & 21.15 \\
\hline 6 & $\mathrm{~T}_{6}$ & 0.38 & 0.72 & 20.27 \\
\hline 7 & $\mathrm{~T}_{7}$ & 0.22 & 0.92 & 24.20 \\
\hline \multicolumn{2}{|c|}{$\mathrm{SEm}+$} & 0.0321 & 4.01 & 1.201 \\
\hline \multicolumn{2}{|c|}{$\mathrm{CD}$} & 1.1091 & 12.98 & 5.29 \\
\hline \multicolumn{2}{|c|}{$\mathrm{CV}(\%)$} & 9.891 & 10.14 & 14.891 \\
\hline
\end{tabular}

Table 2: Yield contributing traits as influenced by Prosopis juliflora, Notchi leaf extracts; and Vermiwash sprays

\begin{tabular}{|c|c|c|c|}
\hline Sl.No. & Treatments & No. of fruits/plant & $\begin{array}{c}\text { Green chillies } \\
\text { yield }(\mathrm{q} / \mathrm{ha})\end{array}$ \\
\hline 1 & $\mathrm{~T}_{1}$ & $231.45^{\mathrm{d}}$ & $207.90^{\mathrm{c}}$ \\
\hline 2 & $\mathrm{~T}_{2}$ & $235.25^{\mathrm{c}}$ & $211.30^{\mathrm{bc}}$ \\
\hline 3 & $\mathrm{~T}_{3}$ & $240.23^{\mathrm{bc}}$ & $216.50^{\mathrm{bc}}$ \\
\hline 4 & $\mathrm{~T}_{4}$ & $254.10^{\mathrm{ab}}$ & $228.20^{\mathrm{a}}$ \\
\hline 5 & $\mathrm{~T}_{5}$ & $240.51^{\mathrm{bc}}$ & $216.89^{\mathrm{bc}}$ \\
\hline 6 & $\mathrm{~T}_{6}$ & $235.24^{\mathrm{c}}$ & $211.28^{\mathrm{bc}}$ \\
\hline 7 & $\mathrm{~T}_{7}$ & $262.50^{\mathrm{a}}$ & $229.80^{\mathrm{a}}$ \\
\hline & Mean & $\mathbf{2 4 2 . 7 4}$ & $\mathbf{2 1 7 . 4 0}$ \\
\hline
\end{tabular}

In a column, means followed by a common letter (s) are not significantly different at 5 per cent level by DMRT.

The results revealed that among the various treatments experimented, application of five sprays of Prosopis juliflora leaf extract (20ml/lit. of water), Notchi leaf extract (20ml/lit. of water), Vermiwash (1:2 dilutions) and Recommended dose of Fertilizers (RD) registered significantly lower thrips mean population of 0.23 per leaf and the value was at par with fortnight interval spray of chemicals along with Recommended dose of Fertilizers(0.22 mean thrips population per leaf). The similar results were observed by Saumya George et.al.,in 2007 who reported six sprays of vermiwash $1: 1$ with organic amendments recorded significantly lower mean indices of thrips which was comparable to the standard check .

The results from treamentT4 was followed by application of Prosopis juliflora leaf extract (20ml/lit. of water), Notchi leaf extract(20ml/lit. of water),Vermiwash $1: 4$ and $\mathrm{RD}(\mathrm{T} 5)$, where the mean population of thrips per leaf was 0.34. The present study is in close accordance with this report of Giraddi et al. (2003) with respect to efficacy of vermiwash and leaf extracts of pungan who also reported signficantly lower thrips and mites population in chilli applied with foliar spray of vermiwash at 60 and 75 days after transplanting as compared to untreated crop .

The parameters on yield and its contributing traits viz., Plant height $(\mathrm{cm})$, Number of fruits/plant and yield of dry chilli (q/ha)in the present study revealed that T7 (0.92 m; 262.50 and 235.80 respectively) is very close to the results with T4 (0.84 m;254.10and 228.20 respectively) where organic amendments of Prosopis juliflora leaf extract $(20 \mathrm{ml} / \mathrm{lit}$. of water) in combination with Notchi leaf extract(20ml/lit. of water and Vermiwash 1:2 along with Recommended dose of fertilizers alone used for managing the thrips populations with respect to yield. This might be due to the efficacy of Prosopis juliflora (Zimmermann,1991) in conjunction with notchi plant extracts intersect in egg laying sites of thrips and elucidate the synergestic action of metabolites against sucking pests as repelents. Similar results in plants with insecticidal activities against four major insect pests in Pakistan were studied by Anwar et.al.,in 1992.

While, the parameter, Number of secondary branches per plant for the treatment $\mathrm{T} 4$ was still closer to the value $(24.30 \mathrm{~cm})$ obtained in $\mathrm{T} 7(24.20 \mathrm{~cm})$ which, contributes in higher number of fruits per plant followed by yield per hectare. The significant increase in all growth parameters in vermiwash treated plants may be due to the significant 
increase in the absorption of major plant nutrients such as $\mathrm{N}$, $\mathrm{P}$ and $\mathrm{K}$ by plants as experimented by Devan et.al.,(2013) in Abelmoschus esculentus. This clearly indicates that vermiwash is suitable for quick absorption of the major nutrients and provides enhanced nourishment for plants (Meyer,1993). These results proved that organic fluids could be promoted to obtain safe and chemical free chillies without affecting yield. Bucker field et al. (1999) in radish and Thangavel et.al.,(2003) in paddy, who they reported similar results in weekly applications of plant extract along with vermiwash which increased both growth and yield.

\section{References}

[1] Buckerfield, J. C., Flavel, T. C., Lee, k. E., Webster, K.A., Diazcozin, D. J., Jesus, J. B., Trigo, D. and Garvin, M. H., 1999, vermicompost in solid and liquid forms as a plant growht promoter. sixth international symposium on earthworm ecology, vigo, sain, 1998, pedobiologia , 43:753-759.

[2] Devan, E., Patheri K. K., Mujeera F.and Maduriveeran, H. 2013. Influence of Vermiwash and Plant growth regulators on the Exomorphological characters of Abelmoschus esculentus (Linn.) MoenchAfrican Journal of Basic \& Applied Sciences 5 (2): 82-90.

[3] Giraddi, R. S., smitha, M. S. and channappagoudar,B. B., 2003, Organic amendments for the management of chilli (cv. Byadagi kaddi) insect pests and their influence on crop vigour. Proceedings of National Seminar on Perspective inSpices, Medicinal and Aromatic Palnts, ICAR Complex, Goa,27-29 November, 2003.

[4] Lewis, $\mathrm{T}$ (1997). Thrips as crops pests. CAB International. Wallingford, UK. pgs.740

[5] Meyer, B.S. Aderson, D.B. Bohning, R.H. and Pratianne. D.C. 1993. Introduction to plant physiology. D'ran Nustard Company, New York, p. 540.

[6] Reddy, D. N. R. and Puttaswamy, 1984, Pest infesting chilli (Capsicum annuum L. ) - In the transplanted corp . MysoreJournal of Agricultural Sciences, 19: 236-237.

[7] Saumya george, R. S. Giraddi,r. H. . Patil .2007. Utility of Vermiwash for the Management of Thrips and Mites on Chilli (Capsicum annuum L.) Amended with Soil Organics* Karnataka J. Agric. Sci., 20(3): 657-659

[8] Spears BM. 2006. USDA-APHIS-PPQ-CPHST, New Pest Advisory Group (NPAG) March 3, 2006 report.

[9] Thangavel, P., Balagurunathan, R., divakaran,J.And prabhakaran,J., 2003, Effect of vermiwash and vermicast extracton soil nutrient status, growth and yield of paddy. Advances of Plant Sciences, 16: 187190.

[10] Anwar, T., Jabbar, A . Khalique, F . Tahir, S and M. A. Shakeel- 1992. Plants with insecticidal activities

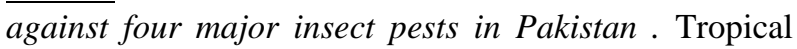
Pest Management .38:4 ; 431-437.

[11]Zimmermann, H.G. .1991.Biological control of mesquite, Prosopis spp. (Fabaceae), in South Africa.Agriculture, Ecosystems \& Environment.37:1-3 175-186. 